\title{
Goal-Setting and Performance Measurement in Transportation Planning and Programming
}

\author{
Darwin G. Stuart \\ Chicago Transit Authority
}

\begin{abstract}
A series of examples from highway planning, transit planning, and multimodal planning/programming is reviewed. The role of more systematic application of transportation goals and objectives and associated performance measures is explored. The need to connect with the overall planning/management structure of an agency is stressed. Distinctions are made between process-oriented and product-oriented goals, contrasting internal administrative measures with output or performance-oriented measures. Several multimodal planning studies are further contrasted with regard to their extent of employing product-oriented performance measures. A checklist for improved goal-setting is given.
\end{abstract}

\section{Introduction}

More thorough and systematic approaches to capital/maintenance project programming in transportation proceed logically from careful consideration of the goals set for these projects. Quantitative treatment of transportation goals and objectives has, in fact, been pursued in recent years from several different perspectives: to aid in carrying forward the management systems initially re- 
quired under ISTEA (Albertin et al. 1995); to enable meaningful system performance monitoring (Hartman etral. 1994); as a part of goals-directed strategic planning/management (Fielding 1987); to assist in formalizing the inputs of multiple public agencies and community groups in transportation planning and decisionmaking (Humphrey 1995); as a basis for strengthening multimodal and intermodal planning (DeCorla-Souza and Jensen-Fisher 1994); and in other ways (Horiwitz and Beimborn 1995).

Experience has shown, however, that, although formal consideration of goals/ objectives represents a logical starting point for improved programming procedures, this has been accomplished with varying degrees of completeness:

- In some instances, goals/objectives are only implicitly employed, rather than explicitly treated.

- In many cases, precise quantitative measurement of goal-achievement is not possible; qualitative and judgmental estimates are necessary.

- Competition between goals quickly enters the process, with complex trade-offs of one against another required.

- The number of goals requiring consideration can grow quickly, leading to the development of hierarchies or networks and associated complexities in defining relationships.

- While goals can clarify the different agendas that multiple participants in planning/programming bring to the table, they can also exacerbate tensions and conflicting points of view.

- Consequently, it is sometimes easier to agree on projects than on goals.

The purpose of this paper is to explore the role of more systematic treatment of goals and objectives in improving transportation programming processes, through the examination of several examples from highway planning, transit planning, and multimodal planning. Comparison of these examples quickly shows that there are many different approaches to the topic, and certainly no one can be singled out as "correct." In fact, connecting to the broader planning/management structure of the agency or agencies involved, and meeting the informational needs of the political decisionmaking processes that ultimately implement plans and 
programs, are the major site-specific determining factors regarding the "fit" of systematic goals identification (Pratt and Lomax 1994). A major theme in comparing the case studies is the extent to which they employ "process-oriented" goals vs. "product-oriented" goals. The former address mainly the administrative side of implementing transportation projects, while the latter attempt to bring in the socio-economic/environmental functions, services, and impacts involved.

\section{Process vs. Product-Oriented Goals}

Three recent NCHRP/TCRP reports review the complexities of goals/objectives analysis from a process vs. product dimension.

A review and compendium of state transportation performance measures, covering both highway and public transportation programs, as well as related programs, included both process-oriented and product-oriented measures (Reed 1993). In general, the goals to which these measures relate are left to the reader and individual state departments of transportation (and others) to define in terms of their own specific contexts. Table 1 summarizes the 38 measures identified, breaking them into five program-performance categories: administrative, highway program, public transportation program, motor vehicle program, and other state transportation programs.

The nine administrative performance measures are clearly process-oriented and monitor the management side of agency activities, with no direct connection to user-oriented performance of transportation systems. Nineteen of the 23 measures of highway program performance are also essentially process- or supplyoriented, in that they represent various aspects of facility condition/serviceability; condition, funding and cost trends for various dimensions of project implementation (including both construction and maintenance); and related administrative aspects. The four product- or demand-oriented measures include highway safety, congestion, cost, and air quality. The four categories of public transportation program-performance measures include both process and product-oriented measures, but with an emphasis on the latter, distinguishing urban and rural operating cost-effectiveness, in particular. 


\section{Table 1}

\section{State Transportation Program Performance Measures}

Generalized Measure

Illustrative Example

\section{ADMINISTRATIVE}

- Overall Efficiency of Administrative Services

- Labor Cost

- Employees' Health

- Overtime

- Employee Safety

- Equal Employment Opportunity (EEO)

- Disadvantaged/Women Business Enterprise (DBE/WBE) Utilization

- Budget

- Cash

\section{HIGHWAY PROGRAM}

- Interstate Highway System Serviceability (Sufficiency)/Need

- Serviceability (Sufficiency)/Needs of Primary/Secondary State Highways

- Bridge Structural Sufficiency/Needs

- Bridge Functional Sufficiency/Needs

- Highway Pavement Condition

- Highway Safety

- Congestion

- Long-Range Program Goals

- Federal-Aid Funds

- State-Aid Funds

- Preconstruction Project Development

- Construction Management 5-year trend of program costs, by support services program

Proportion of annual program expenditures for salaries and fringe benefits

Sick leave hours taken vs. earned

Overtime costs as proportion of total labor costs

Annual days lost due to accidents

Proportion of minority employees hired

Proportional dollar volume of contracts executed

Actual vs. planned expenditures

Actual vs. planned cash on hand

Mileage not meeting state design, mobility, safety, and pavement condition standards

Mileage rated as good to excellent, fair, and poor

Number of bridges not meeting federal/state load carrying capacity standards

Number of bridges not meeting federal/state functional standards

Mileage rated as good to excellent, fair, and poor

Traffic fatality rate

Number of intersections or route segments removed from "most congested" lists

Mileage let to construction contract

Proportion of total annual federal obligational authority committed

Proportion of annual appropriation of state-aid funds committed

Proportion of construction award cost for expenditures devoted to preconstruction activities

Proportion of final construction cost devoted to management activities 
Table 1 (continued)

Generalized Measure

Illustrative Example

- Interstate Hwy System Maintenance Maintenance cost per lane-mile

- Maintenance of Other Primary Hwys Maintenance cost per lane-mile

- Maintenance of Secondary Hwys Maintenance cost per lane-mile

- Construction Contract Cost Proportion of finalized projects whose costs were more or less than $5 \%$ over total award cost

- Construction Contract Schedule Proportion of finalized contracts completed within scheduled time period

- Preconstruction Cost Control Difference between contract award costs and initial programmed costs

- Contractor Payment Schedule

Amount of delinquent interest payments made to contractors

- Advertisement Schedule

Proportion of projects that met annual planned schedule

- Equipment Total equipment downtime, by class

- Cost Annual program cost per vehicle-mile, highway mile, and lane-mile

- Air Quality Annual progress in meeting carbon monoxide standards

\section{PUBLIC TRANSPORTATION PROGRAM}

- Urban Service

- Urban Operating Cost-Effectiveness

- Rural/Community Service/Operating Cost-Effectiveness

- Capital Cost-Effectiveness

\section{MOTOR VEHICLE PROGRAM}

- Service

- Cost
Annual revenue passengers per mile of service, by operator

Total annual operating cost per mile of service, by operator

Annual revenue passengers per mile of service, average operating assistance per revenue passenger

Annual capital expenditures per revenue passenger

Average processing time for drivers' license renewal

Average annual cost per drivers' license renewal

\section{OTHER STATE TRANSPORTATION PROGRAMS}

Annual costs and services, by program area

NOTE: Multiple measures are typically suggested under each generalized measure. The illustrative example is only one of these.

Source: Reed, Luettich, and Lamm, 1993 
In the transit planning arena, process-oriented measures have been defined as "service input," with the notion of efficiency defined as more of an internal measure, describing how well factors such as labor, equipment, facilities, and fuel are utilized (Hartman et al. 1994). It is quite appropriate for such internal or agency-directed goals/objectives to be defined to provide a management control system for monitoring and improving transit services.

Product-oriented goals, on the other hand, address externally-directed transit performance in terms of effectiveness in meeting the expectations of users and non-users of transit services. Here, goals are often set for meeting overall community transportation needs. Such needs can vary widely according to the size and density of communities served, the network coverage and peak/off-peak service frequency associated with such development patterns, and the resultant quality of service. Effectiveness and product-oriented goals can quickly become complex.

Table 2 summarizes the basic transit performance indicators identified in this research effort (Hartman et al. 1994, Carter and Lomax 1992). They add the additional dimension of integrating efficiency and effectiveness measures by computing performance rates such as cost per vehicle-mile or cost per vehicle-hour, which produce more useful cost-efficiency and cost-effectiveness measures.

In a recent review of the analysis and evaluation procedures used in multimodal highway/transit planning, it was found that the concept of "screening criteria" was a way to both incorporate process/product objectives and to stage the project evaluation and prioritization process (Rutherford 1994). In examples cited herein (Rutherford 1994, California Transportation Commission 1990, Younger and Murray 1994), most of the screening criteria employed really had to do with passing muster with other parallel planning/management programs, which essentially represents meeting process-oriented goals. For example, projects worthy of further consideration were required to be consistent with the most recent local air quality plan, the Regional Transportation Plan, and a mandated pavement management program; show evidence that the operating agency had certified its willingness and ability to maintain and operate the facility; af- 


\begin{tabular}{|c|c|}
\hline \multicolumn{2}{|c|}{ Public Transit Performance Measures } \\
\hline Performance Measure. & Performance Indicators \\
\hline Cost Efficiency & $\begin{array}{l}\text { Cost per mile } \\
\text { Cost per hour } \\
\text { Cost per vehicle } \\
\text { Ridership per expense }\end{array}$ \\
\hline Cost Effectiveness & $\begin{array}{l}\text { Cost per passenger trip } \\
\text { Revenue per passenger trip } \\
\text { Ridership per expense }\end{array}$ \\
\hline Service Utilization/Effectiveness & $\begin{array}{l}\text { Passenger trips per mile } \\
\text { Passenger trips per hour } \\
\text { Passenger trips per capita }\end{array}$ \\
\hline Vehicle Utilization/Efficiency & Miles per vehicle \\
\hline Quality of Service & $\begin{array}{l}\text { Average speed } \\
\text { Vehicle miles between road calls } \\
\text { Vehicle miles between accidents }\end{array}$ \\
\hline Labor Productivity & $\begin{array}{l}\text { Passenger trips per employee } \\
\text { Vehicle miles per employee }\end{array}$ \\
\hline Coverage & $\begin{array}{l}\text { Vehicle miles per capita } \\
\text { Vehicle miles per service }\end{array}$ \\
\hline Source: Hartman et al. 1994; Cart & nd Lomax 1992 \\
\hline
\end{tabular}

firm local funding contributions by the responsible local agency; and be in compliance with.Americans with Disabilities Act (ADA) and ISTEA requirements, as applicable.

At the next stage in both examples, sets of more quantitative, as well as qualitative, criteria were then employed. These tended to be a mix of both process- and product-oriented criteria and represented the primary opportunity for product/effectiveness-oriented criteria to come into play. A sampling of these 
criteria, distilled from one of the two examples under discussion (California Transportation Commission 1990), aree given in Table 3. Note that the primary effectiveness measures used deal with vehicle-carrying and person-carrying capacity at free-flowing and peak-hour demand levels (with various underlying assumptions regarding acceptable peak-hour speeds, vehicle occupancy, and treatment of "unmet" demand), consideration of person-delay hours, extent of high-congestion hours of weekly operation, capital costs per units of added capacity, and units of delay saved.

Table 3

Illustrative Project Evaluation Sheet: Quantitative Criteria

Criteria

Highway, Street Transit and Road Projects Projects

1. Project Improvements

- Capacity after project (Veh/Hr)

(Pers/Hr)

- Peak Hour:Volume (Pers/Hr)

Level of Service \& Speed

Demand/Capacity

Load Factor Volume/Capacity

- Peak

- Off-Peak

- Duration of: LOS E or F (Hr/Wk)

Peak Loads (Hr/Wk)

- Estimated Person/Rider Delay (Hr/Yr)

$\mathrm{x}$

$x$

$\mathrm{x}$

$\mathrm{x}$

$\begin{array}{cc} & \mathrm{x} \\ & \mathrm{x} \\ \mathrm{x} & \mathrm{x} \\ & \mathrm{x}\end{array}$

2. Cost Effectiveness

- Capital cost/added capacity

- Capital cost/delay saved

$\begin{array}{ll}\mathrm{x} & \mathrm{x} \\ \mathrm{x} & \mathrm{x}\end{array}$

3. Local Financial Participation

$\mathrm{x}$

$\mathrm{x}$

Source: Rutherford, 1.994; California Transportation Commission, 1990. 


\section{Connecting to the Broader Planning/Management Structure of the Agency}

State DOT responses to the six management systems mandated by ISTEA offer a primary example of the ongoing management and decisionmaking with which meaningful goals analysis must be connected. Of particular importance is the requirement that these management systems be developed on a multimodal basis, both in terms of agencies receiving federal highway or transit funds, and via coordination at the metropolitan planning level with appropriate regional/ local agencies. Goal-oriented programming (GOP) has been used in the state of New York to tie these management systems to the broader decisionmaking process for transportation investments in the State (Shufon et al. 1994). While policy guidance and goals are expected to be determined in the Central DOT office, management systems themselves will continue to be carried forward within the present decentralized decisionmaking environment at regional and district office levels.

The New York Department of Transportation (NYDOT) has indicated that:

the GOP process is the primary mechanism for planning, evaluating, implementing, and monitoring the department's transportation program efforts. Originally designed to address the capital program, it was broadened in 1992 to reflect such noncapital activities as maintenance and operational work performed by state forces. GOP provides a method to manage the program by establishing goals, setting clear measurable objectives, and then measuring program performance in attaining those goals and objectives. The GOP product is a recommended program of projects explicitly balancing needs, priorities, and resources.

Historically, the GOP process has addressed the department's bridge, pavement, capacity, and safety programs. Implementation of the ISTEA management systems provides the opportunity to sharpen decision-making for those program areas and, for the first time, to include transit and intermodal elentents in the programming process. Ultimately, the management systems are intended to 
provide the consistent data, analysis tools, and administrative procedures to assist decișion-makers in making the best decisions, within and across all functional areas. The development of multimodal solutions to transportation problems is a goal of ISTEA. The department's GOP process serves as the framework to achieve that goal. (Shufon et al. 1994)

Figure 1 indicates how this GOP process (at a simplified level) is integrated within broader decisionmaking and management systems. Note that the GOP leads directly to performance measures used as input to the allocation of capital and operating funds among the department's 11 regions. Each regional DOT office then develops annual five-year programs of capital and operations projects, including maintenance. Each regional office works with MPOs, local governments, and transit providers in this program development phase. The program review phase includes evaluation of alternatives with regard to forecasts of trans-

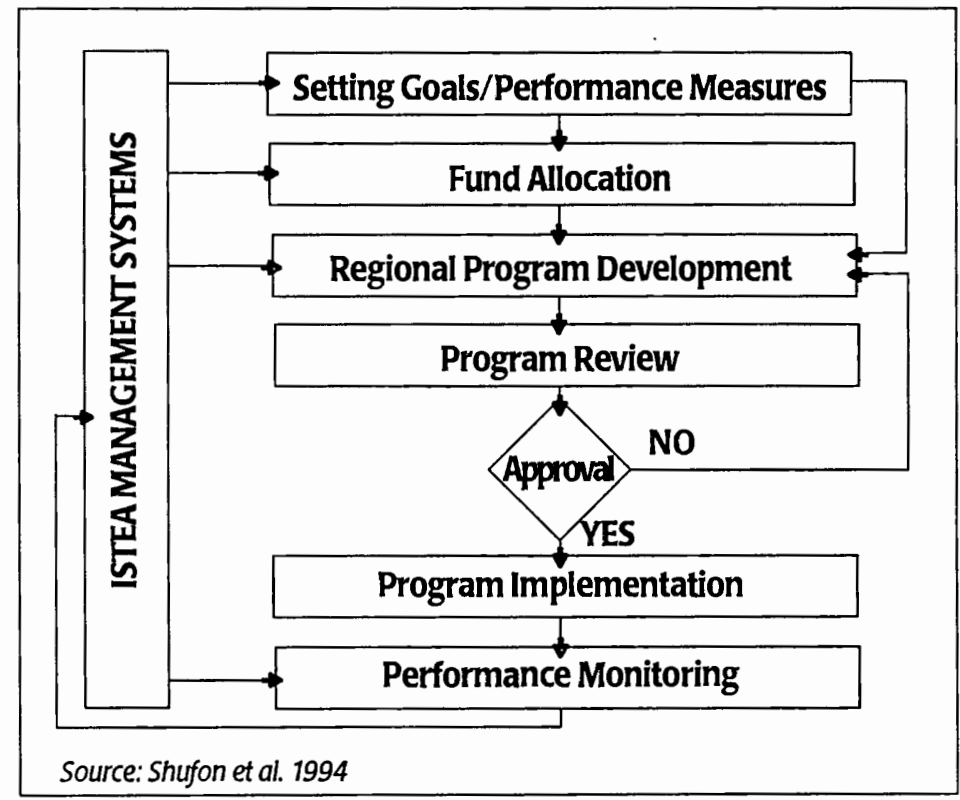

Figure 1. Integrating management systems into the NYSDOT GOP process. 
portation performance and associated direct/indirect impacts, tying back to the statewide goals and performance measures.

The Federal Transit Administration (FTA) is currently involved in defining a Transit Performance Monitoring System (TPMS), intended for use at the metropolitan level, which addresses important user-oriented policy issues (Williams 1994). These issues address the role of transit in pursuing three broad urban policy goals: livable communities, or, alternately, efficient metropolitan areas; congestion management (on the highway network); and low-cost basic mobility. These broad policy areas have important non-transit "driving forces," including urban development/density patterns, commuter mode-choice options in major travel corridors, and the socio-economic consequences of mobility, respectively.

This FTA work is useful because it: (a) addresses complex inter-agency and multimodal policy issues that suggest correspondingly complex goal-setting needs at the metropolitan level; (b) further defines the challenge before highway, transit, and other governmental agencies to address overlapping policy/goal areas in defining alternative multimodal solutions; and (c) illustrates the need to integrate something like a TPMS within the management structure of metropolitan, state, and federal transit/transportation agencies starting, with this concept, at the national level.

Table 4 summarizes these interagency goal/policy areas, according to a preliminary analysis of 1990 National Personal Transportation Study survey results. The finding that transit trips are commonly made in pursuit of overlapping policy/ goal areas enforces both the complexity of goals analysis and appropriate interagency response. Note that about half of observed transit trips serve more than one goal/policy function, with the largest overlap between supporting livable communities and corridor congestion management. Approximately half of transit trips ( 31 percent +3 percent $=34$ percent, in Table 4 ) made in "livable areas" simultaneously help manage congestion by offering a transit alternative to congested highways. Other overlaps are smaller, but still indicative of the need to explicitly recognize multiple objectives for transportation programs. (For example, more than one-third of transit trips made in pursuit of low-cost mobility goals were associated with livable community functions.) 


\section{Table 4 \\ Initial Specificătion of Urban Transit Functions}

\begin{tabular}{|c|c|c|c|c|c|c|c|c|}
\hline \multirow[b]{2}{*}{$\begin{array}{l}\text { Urban } \\
\text { Transit } \\
\text { Functions }\end{array}$} & \multicolumn{3}{|c|}{ Variables Defining Transit Functions } & \\
\hline & $\begin{array}{c}\text { Transit } \\
\text { Intensity }\end{array}$ & $\begin{array}{l}\text { Household } \\
\text { Income }\end{array}$ & $\begin{array}{c}\text { Trip } \\
\text { Purpose }\end{array}$ & $\begin{array}{c}\text { Single } \\
\text { Function } \\
\text { (\%) }\end{array}$ & $\begin{array}{r}n \text { Ove } \\
F u\end{array}$ & rlappin & $n g$ & $\begin{array}{r}\text { Total } \\
\text { (\%) }\end{array}$ \\
\hline Livable & Rapid Rail UZA & Above poverty & Non-work trip & 25 & - & $\because$ & -- & 69 \\
\hline Community & Rapid Rail UZA & Poverty & Work Trip & -- & 3 & -- & -- & - \\
\hline \multirow[t]{2}{*}{ Function* } & Rapid Rail UZA & Poverty & Non-work trip & - & - & 10 & -. & - \\
\hline & Rapid Rail UZA & Above poverty & Work trip & - & 31 & - & - & - \\
\hline Congestion & Non-Rail UZA & Abov & Work trip & 9 & -- & - & - & 45 \\
\hline Management & Rapid Rail UZA & Above poverty & Work Trip & -- & 31 & - & - & -- \\
\hline \multirow[t]{2}{*}{ Function* } & Rapid Rail UZA & Poverty & Work trip & -- & 3 & -. & - & -- \\
\hline & Non-Rail UZA & Poverty & Work trip & - & - & - & 2 & - \\
\hline Low-Cost & Non-Rail UZA & Po & Non-work trip & 6 & - & - & -- & 35 \\
\hline Mobility & Non-Rail UZA & Poverty & Work Trip & - & -- & -- & 2 & - \\
\hline \multirow[t]{3}{*}{ Function* } & Rapid Rail UZA & Poverty & Work trip & - & 3 & - & - & - \\
\hline & Rapid Rail UZA & Poverty & Non-work trip & - & - & 10 & -- & - \\
\hline & Non-Rail UZA & Above poverty & Non-work trip & 14 & - & -- & -- & - \\
\hline
\end{tabular}

*The defining variables for each function are italicized.

Source: 1990 Nationwide Personal Transportation Survey Data Files, as reported in Williams 1994.

\section{Product-Oriented Performance Measures}

A first-cut review of the evaluation criteria utilized in a number of different multimodal planning/programming efforts, in relation to the three broad interagency goal/policy areas driving the TPMS work, clearly shows the multimodal nature of the latter (Rutherford 1994). In general, as indicated in Table 5, these criteria involve measures by which associated goals/objectives, in the 16 different categories given, might be gauged. The fact that implied TPMS goals are largely user-oriented is reflected in the realization that only the first 5 of the 16 goal/criteria categories correspond to the three broad goal/policy areas of livable communities, congestion management, and low cost mobility.

Note that the goal/criteria categories of "System Development, Coordination and Integration" and "Land Use" expand the concept of "livable communities" by suggesting land-use/transportation relationships. In Table 4, livable communities were implicitly defined in terms of the urban development and density 
Table 5

Classification of Criteria: Multimodal Transportation Plan Evaluations

\begin{tabular}{lll} 
General Category & Typical Criteria & $\begin{array}{l}\text { TPMS } \\
\text { Goal/P } \\
\text { Areas }\end{array}$ \\
\hline $\begin{array}{lll}\text { 1. Transportation System } \\
\text { Performance }\end{array}$ & $\begin{array}{l}\text { - Number of trips by mode } \\
\text { - Vehicle miles traveled } \\
\text { - Congestion } \\
\text { - Peak hour congestion } \\
\text { - Transit boardings } \\
\text { - Highway level of service }\end{array}$ & \\
& A, B, C \\
\hline
\end{tabular}

2. Mobility

- Mobility options

C

- Improved movement of people

3. Accessibility

- $\%$ within 30 minutes, etc.

A, B

- Transit and highway speeds

4. System Development, Coordination and Integration
- Terminal transitions

- Transportation system development

- Regional importance

- Projects in existing plans

5. Land Use

- Compatibility with land use plans

- Growth inducement

- Reduced goods movement costs

6. Freight

- Homes or businesses displaced

7. Socioeconomic

- Maximize economic benefit

- Historic impacts

- Construction employment

8. Environmental

- Air quality

- Sensitive areas

- Natural environment

9. Energy

- Energy consumption

10. Safety

- Annual accidents by mode

- Safety ratings

11. Equity

- Equity of benefit and burden

12. Costs

- Capital costs

- Operating costs 
Table 5 (continued)

\begin{tabular}{lll} 
& Table 5 (continued) & \\
\hline General Category & Typical Criteria & $\begin{array}{l}\text { TPMS } \\
\text { GoalPolicy } \\
\text { Areas }\end{array}$ \\
\hline 13. Cost Effectiveness & $\begin{array}{l}\text { - Annualized costs per trip or mile } \\
\text { - FTA (UMTA) index }\end{array}$ & \\
\hline 14. Financial Arrangements & $\begin{array}{l}\text { - Funds required } \\
\text { - Funding feasibility-build/operate } \\
\end{array}$ & - Public/private sources \\
\hline 15. Institutional Factors & - Ease of staging and expansion \\
& - Non-implementing agency support \\
\hline 16. Other & - Fatal flaw & \\
& - Right-of-way opportunities & \\
& - Enforcement & \\
\hline
\end{tabular}

KEY: $\quad \mathrm{A}=$ Livable Communities; $\mathrm{B}=$ Congestion Management;

$\mathrm{C}=$ Low Cost Mobility

Source: Rutherford 1994

patterns that would support a rapid rail transit system, which implies, in turn, sufficient work and non-work travel over that system to achieve acceptable transit cost/revenue performance. Urban and regional goals that address this notion should consequently deal first with the land-use densities necessary to support viable non-automobile (specifically, non-single-occupant vehicle [SOV]) modal options.

Table 5 also clearly illustrates the extent to which systematic goal-setting for transportation systems currently has moved well beyond direct measures of service quality for users. Even though the TPMS concept is first defined in terms of transit trips actually carried in urban areas and consequently deals initially with transportation system performance, mobility, and accessibility goal/criteria categories, it also addresses indirectly the system development/coordination/integration and land use goal/criteria categories. Similar comments apply to the 
highway user-oriented and modal performance-oriented criteria typically most utilized at state and regional planning levels (e.g., as in Table 1). In fact, however, many of these goals/criteria are one step removed from users themselves and reflect simply different measures of the supply of transportation provided (lane-miles by condition, bridges by structure type and condition, etc.). Carrying their implications forward to goal/criteria categories further down the list in Table 5 is also needed.

\section{Comparison of Multimodal Planning Studies}

Table 6 summarizes the extent to which different evaluation criteria (and implied goals/objectives) were actually employed in 18 multimodal planning studies across the country. These studies fall into intercity corridor, regional, urban corridor, and regional programming categories. The number of examples in each category that employs one or more criteria (under the 16 criteria categories) is indicated in Table 6, as well as the total count of different criteria used in all examples of that type.

Table 6 suggests the following:

- Few of the studies employed a wide range of evaluation criteria.

- The regional programming studies considered system coordination and integration much more often than the planning studies.

- The following criteria were left out more often than they were included: mobility, system coordination and integration, land use, freight, energy, safety, cost-effectiveness, equity, financial arrangements, and institutional factors.

- Equity was considered in only one study (conducted under FTA Alternatives Analysis Guidelines).

- Few móbility measures were used, and no multimodal measures of mobility were identified or used.

- Few studies employed a broad enough range of criteria.

- Many criteria used to measure the performance and cost of the transportation system may be redundant when individual studies are more carefully examined. 


\section{Table 6 \\ Comparison bf Criteria Used in Each Category, by Multimodal Study Type}

\begin{tabular}{|c|c|c|c|c|c|c|c|c|}
\hline \multirow[b]{2}{*}{$\begin{array}{l}\text { Criteria } \\
\text { Category }\end{array}$} & \multicolumn{2}{|c|}{ Intercity Corridor } & \multicolumn{2}{|c|}{ Regional } & \multicolumn{2}{|c|}{ Urban Corridor } & \multicolumn{2}{|c|}{$\begin{array}{c}\text { Regional } \\
\text { Programming }\end{array}$} \\
\hline & $\begin{array}{l}\text { amples } \\
\text { Using } \\
\text { Criteria }\end{array}$ & $\begin{array}{r}\text { Sum of } \\
\text { Criteria, } \\
\text { All } \\
\text { Examples }\end{array}$ & $\begin{array}{r}\text { Examples } \\
\text { Using } \\
\text { Criteria }\end{array}$ & $\begin{array}{r}\text { Sum of } \\
\text { Criteria, } \\
\text { All } \\
\text { Examples }\end{array}$ & $\begin{array}{r}\text { Examples } \\
\text { Using } \\
\text { Criteria }\end{array}$ & $\begin{array}{r}\text { Sum of } \\
\text { Criteria, } \\
\text { All } \\
\text { Examples }\end{array}$ & $\begin{array}{r}\text { Example } \\
\text { Using } \\
\text { Criterio }\end{array}$ & $\begin{array}{r}\text { Sum of } \\
\text { Criteria, } \\
\text { All } \\
\text { Examples }\end{array}$ \\
\hline $\begin{array}{l}\text { 1. Transportation } \\
\text { System } \\
\text { Performance } \\
\text { 2. Mobility }\end{array}$ & $\begin{array}{l}3 \\
--\end{array}$ & $\begin{array}{r}12 \\
--\end{array}$ & $\begin{array}{l}4 \\
1\end{array}$ & $\begin{array}{r}18 \\
1\end{array}$ & $\begin{array}{l}7 \\
--\end{array}$ & $\begin{array}{l}50 \\
--\end{array}$ & 2 & $\begin{array}{r}11 \\
2\end{array}$ \\
\hline $\begin{array}{l}\text { 3. Accessibility } \\
\text { 4. System } \\
\text { Development, } \\
\text { Coordination, } \\
\text { and Integration }\end{array}$ & 2 & 4 & -- & 3 & 5 & 13 & - & 13 \\
\hline $\begin{array}{l}\text { 5. Land Use } \\
\text { 6. Freight }\end{array}$ & $\begin{array}{l}1 \\
1\end{array}$ & $\begin{array}{l}2 \\
1\end{array}$ & $\begin{array}{l}2 \\
1\end{array}$ & $\begin{array}{l}5 \\
1\end{array}$ & $\begin{array}{l}2 \\
--\end{array}$ & $\begin{array}{l}9 \\
--\end{array}$ & 3 & $\begin{array}{l}4 \\
3\end{array}$ \\
\hline $\begin{array}{l}\text { 7. Socioeconomic } \\
\text { 8. Environmental }\end{array}$ & $\begin{array}{l}2 \\
1\end{array}$ & $\begin{array}{l}3 \\
2\end{array}$ & $\begin{array}{l}3 \\
4\end{array}$ & $\begin{array}{l}7 \\
7\end{array}$ & $\begin{array}{l}2 \\
3\end{array}$ & $\begin{array}{l}14 \\
14\end{array}$ & 2 & $\begin{array}{l}2 \\
2\end{array}$ \\
\hline $\begin{array}{l}\text { 9. Energy } \\
\text { 10. Safety }\end{array}$ & $\ddot{1}$ & $\ddot{1}$ & $\begin{array}{l}3 \\
1\end{array}$ & $\begin{array}{l}3 \\
2\end{array}$ & $\begin{array}{l}2 \\
2\end{array}$ & $\begin{array}{l}2 \\
6\end{array}$ & 3 & $\begin{array}{l}3 \\
2\end{array}$ \\
\hline $\begin{array}{l}\text { 11. Equity } \\
\text { 12. Costs }\end{array}$ & $\overline{3}$ & $-\overline{5}$ & $\overline{3}$ & $-\overline{6}$ & $\begin{array}{l}1 \\
5\end{array}$ & $\begin{array}{r}1 \\
11\end{array}$ & 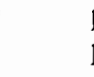 & $\begin{array}{l}1 \\
1\end{array}$ \\
\hline $\begin{array}{l}\text { 13. Cost Effectiveness } \\
\text { 14. Financial Argmts }\end{array}$ & $\begin{array}{c}1 \\
--\end{array}$ & $\begin{array}{c}4 \\
--\end{array}$ & $\begin{array}{l}1 \\
2\end{array}$ & $\begin{array}{l}2 \\
3\end{array}$ & $\begin{array}{l}2 \\
2\end{array}$ & $\begin{array}{l}7 \\
3\end{array}$ & 2 & $\begin{array}{l}6 \\
4\end{array}$ \\
\hline $\begin{array}{l}\text { 15. Institu. Factors } \\
\text { 16. Other }\end{array}$ & $\overline{2}$ & $\overline{2}$ & $\begin{array}{l}2 \\
--\end{array}$ & $\begin{array}{l}4 \\
-\end{array}$ & $\begin{array}{l}1 \\
2\end{array}$ & $\begin{array}{l}1 \\
5\end{array}$ & 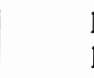 & $\begin{array}{l}1 \\
3\end{array}$ \\
\hline
\end{tabular}

* This column is the total of all criteria used in the case studies for each category, and indicates which categories receive the most emphasis.

Source: Rutherford 1994 
- Other criteria may measure the same underlying feature and thus exaggerate a project's benefits again, when specific criteria in a given study are more carefully examined; an example is different level-of-service measures that all reflect travel time.

The inconsistency with which the non-user-oriented goals/criteria from Table 6 are reflected in these examples is a clear indication of the extent to which goalsetting and the development of associated criteria are a key initial step in planning/programming that is necessarily locally determined. There is no one right way to proceed with this step. In fact, once the details of the participatory process of goal development and associated choices of analysis methods and measures,are examined in individual examples, it becomes evident that they are quite difficult to compare. Some of these site-specific determinants of the details of multimodal evaluation of transportation alternatives include:

- "the purpose of the study (some studies merely quickly screened many alternatives; other studies looked carefully at specific technologies in specific corridors);

- resources available to the study, including both time and funding (these studies obviously ranged greatly);

- government requirements (such as those under the FTA's alternatives analysis guidelines);

- stage in the planning process (some studies may have been preliminary feasibility studies; others were serious alternatives analyses that included some engineering component); and

- nature of the planning area (including size of the area, topography, roads available, and the type of development currently in place)" (Rutherford 1994).

\section{Additional Highway and Transit Planning Examples}

To supplement this review of multimodal examples of planning/programming, two final case studies are presented. One involves the potential application of a normative model of decisionmaking in transit planning by the Ann Arbor Transportation Authority known as Multiattribute Utility Theory (MAUT). The 
second involves a similar more systematic approach to highway project prioritysetting using a method of optimization known as Data Envelopment Analysis (DEA), as developed by the Utah Department of Transportation.

The cornerstone of the MAUT approach lies in explicit development of transit system design objectives, organized in hierarchical fashion, that reflects a full range of user/non-user/management concerns (Reed et al. 1994). Figure 2 gives an illustrative example of such an objectives hierarchy for transit system design, expressing goals in the simplest of terms. For example, given that transit improvements are "desirable overall," three basic goals are then addressed: satisfying transit customers, being technologically implementable, and being financially affordable. Specific objectives and associated measures would then be associated with the user and management concerns listed at the next three levels of the hierarchy.

The Utah example is innovative in its use of an optimization algorithm to select a "best" set of highway projects, which both requires the setting of specific quantitative measures by which priorities are set, and allows the assigning of

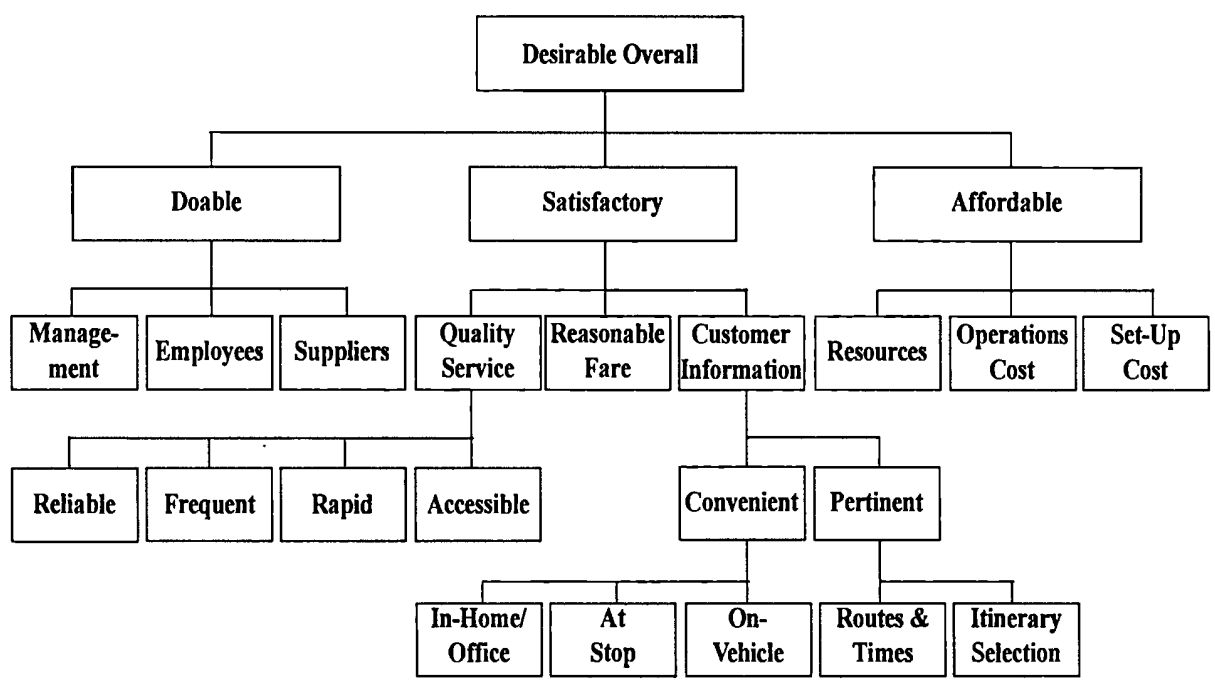

Figure 2. Example objectives hierarchy for transit system design. 
relative weights to those measures, then permitting the calculation of total "scores" for each project (Walter et al. 1993). However, this example is typical of many states in that goals and objectives are not explicitly set, but only implied by the performance, condition, and expected life ratings which are primarily employed.

Table 7 summarizes the variables utilized in the initial delineation of the DEA model. Note that the column labeled "Improvement and Resource Measures" includes a number of different measures of improvement in the highway inventory - additional years of life added, surface condition improvements, expected reduction in accidents, etc. - which represent supply-side measures, akin to the management process-oriented (rather than product-oriented) measures discussed earlier. This column also includes two different measures of average daily traffic, as user or product-oriented measures of impact. Direct and indirect Utah DOT costs are included as inputs. In general, the "Measures of Need" column includes existing condition values for these same output-oriented measures.

\section{Conclusions}

As a logical kick-off point for state, regional, and metropolitan transportation programming efforts, more effective and meaningful goal setting is far from a trivial exercise. As the examples reviewed in this paper show, there are many dimensions by which goal setting can vary, including number of participants, range of concerns and impacts addressed, complexity by which goals are interrelated, all of the technical and judgmental problems associated with criteria for measuring performance in achieving goals, the manner in which goals and objectives are themselves employed in designing alternatives, and, similarly, the role of goals/objectives/criteria (and associated analysis methodologies) in evaluating alternatives. Many procedural and methodological decisions must be made, explicitly or implicitly, in using a goal-setting process to inaugurate or recycle a transportation programming effort.

ISTEA has heightened the sensitivity and increased the experience of the transportation planning community concerning the development of complex sets of goals and objectives for project selection and programming. Specifically, additional attention has been directed at both identifying and measuring some of 


\section{Table 7}

\section{Variables Used to Describe Projects in Initial Implementation of Project Prioritization Model}

\begin{tabular}{|c|c|}
\hline $\begin{array}{l}\text { Dimension of } \\
\text { Concern }\end{array}$ & Measures of Need \\
\hline Level of Service & $\begin{array}{l}\text { - Expected years until actual traffic } \\
\text { volume } \\
\text { - Current Average Daily Traffic (ADT) } \\
\text { volume }(\mathrm{O}) \\
\text { - Design Hourly Volume }(20 \mathrm{yr})(\mathrm{O})\end{array}$ \\
\hline
\end{tabular}
Improvement and Resource Measures

- Additional years added by project until traffic volume exceeds acceptable level of service $(\mathrm{O})$

- Expected change in total traffic (annual ADT) traffic over a $20-y r$ period

\begin{tabular}{|c|c|c|}
\hline $\begin{array}{l}\text { Pavement } \\
\text { Condition }\end{array}$ & $\begin{array}{l}\text { - Yrs of pavement life remaining (I) } \\
\text { - Surface conditions: } \\
\text { a. rut depth (I) } \\
\text { b.index of cracking (I) } \\
\text { c. skid index (I) } \\
\text { - Average daily ESALs (O) }\end{array}$ & $\begin{array}{l}\text { - Additional yrs of life added }(\mathrm{O}) \\
\text { - Surface conditions: expected } \\
\text { improvement resulting from project } \\
\text { a. rut depth }(\mathrm{O}) \\
\text { b.cracking }(\mathrm{O}) \\
\text { c. skid }(\mathrm{O})\end{array}$ \\
\hline Ride & - Expected yrs to ride failure (I) & $\begin{array}{l}\text { - Estimated additional yrs of ride life } \\
\text { resulting from project }(\mathrm{O})\end{array}$ \\
\hline $\begin{array}{l}\text { Condition of } \\
\text { Structures }\end{array}$ & $\begin{array}{l}\text { - Yrs until adequacy of structure falls } \\
\text { below acceptable standard } \\
\text { a. deck (I) } \\
\text { b.structure (I) } \\
\text { c. desk geometry (I) } \\
\text { d.sub-structure (I) }\end{array}$ & $\begin{array}{l}\text { - Additional yrs added by project: } \\
\text { a.deck }(\mathrm{O}) \\
\text { b.structure }(\mathrm{O}) \\
\text { c. deck geometry }(\mathrm{O}) \\
\text { d.sub-structure }(\mathrm{O})\end{array}$ \\
\hline Safety & $\begin{array}{l}\text { - Ratio of actual accident rate to state- } \\
\text { wide accident rate for similar roads } \\
\text { (3-yr average) }(0) \\
\text { - Ratio of actual severity index to } \\
\text { statewide severity index for similar } \\
\text { roads (3-yr period) }(0)\end{array}$ & $\begin{array}{l}\text { - Expected reduction in accidents as } \\
\text { a result of project ( } 3 \text {-yr average) }(0) \\
\text { - Expected change in the severity } \\
\text { index (3-yr average) }(0)\end{array}$ \\
\hline
\end{tabular}

Resources Required

- Direct project costs (I)

- Indirect UDOT costs (I)

- Estimated user costs during construction (I)

Other Relevant

Factors
- Length of project in miles $(0)$ (Optional, used when projects being evaluated have meaningful length)

Note: $(\mathrm{I})=$ input variable, $(\mathrm{O})=$ output variable

Source: Reed et al. 1994 
the goals of transportation that go beyond traditional measures of service supply. While, to date, no standard goal sets or even goal development processes have come to be identified as the prescribed "best" approach, there is a growing, rich understanding of the importance of the goal development process and a growing application of the range of goal types and measurement issues.

Often, public transportation is valued for its ability to attain objectives that go beyond traditional transportation measure sets. The growing complexity of goal set development and measurement offers the opportunity for the public transit community to articulate and measure more of the impacts that public transit can have in a community. As this paper has pointed out, the process is not simple, yet continued progress is necessary to help ensure that decisions reflect, as much as possible, the full sets of goals that characterize the public's intentions.

Outlined below are a set of guidelines for good goal setting that are designed to provide practitioners with guidance as they pursue goal setting for project selection and programming.

- Reflect the concerns of both users and non-users who may be significantly impacted by transportation facility construction/operation.

- As a result, offer the opportunity for interagency and community group participation in goal setting.

- Consider explicitly the measures/criteria that may or should apply in operationalizing goals assessment.

- Depending upon the complexity that emerges, utilize goals/objectives/ criteria hierarchies as appropriate to show interrelationships and priorities.

- In general, recognize that there is an ongoing need tostep back from traditional supply-oriented performance measures to ask, "What difference do these measures make to system users?" and to explore supplemental measures and goals that relate more directly to user (and nonuser) benefits and costs.

- Give particular attention to how comparàtaive mobility delivered by alternate modes can/should be defined and measured. 
- Where qualitative measures are indicated, give thought to how and by whom judgmental estimates of service quality/costs/indirect impacts will be made.

- Begin to anticipate implications for the ensuing process of analysis/forecasting of the impacts of transportation alternatives.

- Travel demand forecasts

- Indirect impact analyses

- Life cycle cost analyses

- Travel time savings and value of time analyses

- Begin to anticipate the data and judgment needs of the ensuing process of evaluating transportation alternatives:

- Assigning relative weights to goals/criteria

- Accommodating conflict and trade-offs among goals and objectives

- Deriving single summary scores, such as cost-effectiveness indices or other cost/performance measures, for alternatives

- Accommodating the substitution of alternative projects at the cost/effectiveness trade-off margin, given that a budget limit has been reached

- Recognize that there is no single best method for goal-setting, particularly given the different scales of planning (regional, corridor, project, etc.) and levels of detail at which planning may be done.

- Recognize that much discretion remains to state, regional, and local participants in goal-setting for transportation planning/programmingand effective interaction among participants in achieving this is its own additional benefit.

\section{Acknowledgment}

An earlier version of this paper was presented at the Conference on Transportation Programming Methods and Issues, Transportation Research Board, Irvine, California, December 3-6, 1995.

\section{References}

Albertin, R., J. Romeo, L. Weiskopf, J. Prochera, and J. Rowen. 1995. "Facilitating Transportation Agency Management Through Performance Measurement: NYSDOT Ex- 
perience with Management Performance Indicator Report." Paper presented at Transportation Research Board Annual Meeting, January.

California Transportation Commission. 1990. "Flexible Congestion Relief Program Guidelines."

Carter, D. N., and T. J. Lomax. 1992. "Development and Application of Performance Measures for Rural Public Transportation." Transportation Research Record 1338. Transportation Research Board: 28.

DeCorla-Souza, P., and R. Jensen-Fisher. 1994. "Comparing Multimodal Alternatives in Major Travel Corridors." Transportation Research Record 1429. Transportation Research Board: 15-23.

Fielding, G. J. 1987. Managing Public Transportation Strategically: A Comprehensive Approach to Strengthening Service and Monitoring Performance. Jossey-Bass Publishers.

Hartman, R. J., E. M. Kurtz, and A. B. Winn. 1994. The Role of Performance-Based Measures in Allocating Funding for Transit Operations. Transit Cooperative Research Program, Synthesis 6. Transportation Research Board.

Horowitz, A. J., and E. Beimborn. 1995. "Methods and Strategies for Transit Benefit Measurement." Paper presented at Transportation Research Board Annual Meeting. Humphrey, T. F. 1995. Consideration of the 15 Factors in the Metropolitan Planning Process. National Cooperative Highway Research Program, Synthesis 217. Transportation Research Board.

Pratt, R. H., and T. J. Lomax. 1994. "Performance Measures for Multimodal Transportation Systems." Paper presented at Transportation Research Board Annual Meeting, January.

Reed, M. F., R. A. Luettich, and L. P. Lamm. 1993. Measuring State Transportation Program Performance. National Cooperative Highway Research Program, Report 357. Transportation Research Board.

Reed, T. B., C.C. White III, M.P. Bolton, and W.D. Hiller. 1994. "Application of Multiattribute Theory to Public Transit System Design." Transportation Research Record 1451. Transportation Research Board: 37-43.

Rutherford, G. S. 1994. Multimodal Evaluation of Passenger Transportation. National Cooperative Highway Research Program, Syntheșis 201. Transportation Research Board. 
Shufon, J. J., C. R. Fosdick, B. P. Gigliotti, and J. P. McClean. 1994. "Developing and Implementing the Intermodal Surface Transportation Efficiency Act Management Systems: New York State's Approach." Transportation Research Record 1450. Transportation Research Board: 80-6.

Walter, L. C., G. Thurgood, and D. L. Adolphson. 1993. "New Approach to Integrating Engineering, Managerial, and Political Judgment: Development of the Utah Project Prioritization System." Transportation Research Record 1400. Transportation Research Board: 1-9.

Williams, F. L. 1994. "The Public Policy Functions of Transit Services" (Draft). Federal Transit Administration, U.S. Department of Transportation.

Younger, K. E., and D. G. Murray. 1994. "Developing a Method of Multimodal Priority Setting for Transportation Projects in the San Francisco Bay Area in Response to the Opportunities in ISTEA," Transportation Research Record 1429. Transportation Research Board: 1-6.

\section{About the Author}

DARWIN G. StuarT is Manager of Market Research at the Chicago Transit Authority where he has been responsible for a variety of system planning, corporate planning, and market analysis activities. He has also worked as a private transportation and transit planning consultant and has been active with Transportation Research Board committee and research panel efforts. He holds a Ph.D. from Northwestern University. 